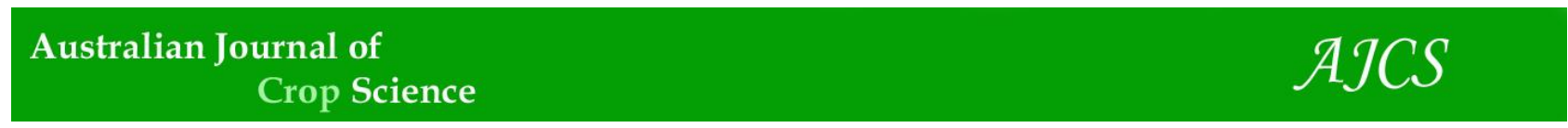

AJCS 15(08):1139-1145 (2021)

ISSN:1835-2707

doi: 10.21475/ajcs.21.15.08.p3162

\title{
Grain sorghum under pre- and post-flowering drought stress in a semiarid
} environment

\section{Andrey Antunes de Souza ${ }^{1}$, Abner José de Carvalho ${ }^{1}$, Edson Alves Bastos ${ }^{3}$, Milton José Cardoso ${ }^{2}$, Marcos Paulo Mingote Júlio ${ }^{3}$, Paulo Sérgio Cardoso Batista ${ }^{1}$, Bruno Henrique Mingote Julio ${ }^{3}$, Carmela Vaz Campolina $^{3}$, Arley Figueiredo Portugal ${ }^{1}$, Cícero Beserra de Menezes ${ }^{4}$, Simônica Maria de Oliveira ${ }^{1}$}

\author{
${ }^{1}$ State University of Montes Claros - Campus Janaúba, Janaúba, MG, Brazil \\ ${ }^{2}$ Embrapa Mid-North, Teresina, PI, Brazil \\ ${ }^{3}$ Federal University of São João del-Rei - Campus Sete Lagoas, Sete Lagoas, MG, Brazil \\ ${ }^{4}$ Embrapa Maize and Sorghum, Sete Lagoas, MG, Brazil
}

*Corresponding author: simonica.agronomia@gmail.com

\begin{abstract}
Sorghum is one of the most drought-tolerant cereals. However, strong water stress, especially during the reproductive phase, causes significant grain yield reduction. Drought events are common in second crops planted after soybean harvest in Brazil. The objective of the present study was to assess grain sorghum hybrids grown under pre- and post-flowering drought stress. Twenty-five hybrids were subjected to two water stress environments (pre- and post-flowering) and one environment with non-water stress. The experimental design was a split plot based on a randomized complete block with three replicates. Water stress pre-flowering reduced plant height, accelerated flowering, and increased panicle index compared with water stress post-flowering. Both pre- and postflowering stress reduced yield, by $45 \%$ and $48 \%$, respectively. Grain mass was greatly affected by stress occurring post-flowering but not by that occurring pre-flowering. Therefore, the reduction in yield caused by pre-flowering stress is due more to the reduction of grain number in the panicle, whereas the reduction when stress occurs post-flowering is due more to reduction in grain size. The plant chlorophyll index decreased when stress occurred pre-flowering and reverted after irrigation had resumed, demonstrating recovery in the photosynthetic capacity of the sorghum plant. With post-flowering stress, the chlorophyll index decreased significantly 30 days after the stress, affecting grain filling, with consequent yield loss.
\end{abstract}

Keywords: Abiotic stress, chlorophyll index, Sorghum bicolor, water stress

Introduction

Sorghum (Sorghum bicolor (L.) Moench) is grown across millions of hectares in Africa, Asia, Oceania, and America. In these continents, there are regions with distinctive edaphoclimatic characteristics that make farming activity difficult, and the ability of plants to withstand water stress is of vital importance for agribusiness development (Shao et al., 2008; Wagaw, 2019). In Brazil, in the 2018/19 season, the sorghum crop occupied an area of 732 thousand hectares, with a yield of $2,973 \mathrm{~kg} \mathrm{ha}^{-1}$ and a production of 2.2 million tons. The states of Goiás, Minas Gerais, and Bahia contain the main production areas (CONAB, 2020). In these regions, sorghum is grown as an off-season crop, after soybean harvesting. This growing season has poor rainfall with erratic distribution, especially in semi-arid regions such as Western Bahia, which also have high temperatures, which intensify water stress and result in reduced yield (Menezes et al., 2015; Batista et al., 2019). Water deficit is directly associated with a reduction in grain and forage production, and also affects some morphophysiological characteristics of plants. Despite being one of the most drought-tolerant cereals, sorghum is affected by long periods of drought. Water stress reduces the chlorophyll index of plants, the number of green leaves (Xu et al., 2000; Magalhães et al., 2010; Mutava et al., 2011; Reddy, 2019), plant height, panicle harvest index, grain number, grain weight, and total yield (Batista et al., 2013; Menezes et al., 2015; Batista et al., 2019). Moreover, the effects of water deficit in sorghum differ depending on whether the stress occurs pre- or post-flowering (Tuinstra et al., 1997; Reddy et al., 2009; Wagaw, 2019). The plant physiological response to drought tolerance may vary according to the severity and interval of the stress, phenological stage, and genetic material (Amelework et al., 2008; Shao et al., 2015). Stress preflowering leads to leaf curl and discoloration, whereas when the stress is post-flowering, plants show symptoms including premature death, stem collapse, and lodging (Rosenow et al., 1996; Belete, 2018). Elucidating how crops respond to these effects is crucial to develop and select drought-tolerant genotypes. Although much is known about the mechanisms that confer tolerance to water stress in sorghum, it is necessary to understand how the plant reacts to factors that limit its development under adverse conditions at different stages of its growth. This information is needed to allow more widespread sorghum cultivation, especially in regions with greater water stress problems. 
Therefore, the objective of the present study was to investigate the effects of water stress on grain sorghum hybrids subjected to stress pre- and post-flowering.

\section{Results}

Plant height and flowering of grain sorghum hybrids grown under non-water stress and water stress at pre-and postflowering

Water stress pre-flowering (PRE) significantly reduced plant height (Figure 1). In this environment, plant heights ranged from 73 to $108 \mathrm{~cm}$, with values lower than the means of the other two environments. Average plant heights of most hybrids were less than $100 \mathrm{~cm}$ in this environment. In the environment with post-flowering water stress (POST), plant height showed greater variation than in the non-stressed environment, and a lower median, indicating that height was also affected by stress, although to a lesser degree than in the pre-flowering stress environment. This reduction is due to the growth of the plant peduncle in the later maturity hybrids, because after flowering, when the stress was imposed, the plant internodes were already formed. The hybrids flowered earlier in the pre-flowering water stress environment (Figure 2), with $50 \%$ of the hybrids flowering between 60 and 62 days after planting, values below those in the other two environments. In the non-water stress environment, flowering varied from 58 to 68 days after planting, with most of the hybrids flowering before 64 days. Post-flowering stress slightly delayed flowering, with most hybrids not flowering until 65 days after planting, but with very little difference relative to the non-stress environment.

Yield and mass of grains of grain sorghum hybrids grown under non-water stress and water stress at pre-and postflowering

Grain yield was significantly affected by water stress. In the non-stress environment, it ranged from 5,580 to $9,719 \mathrm{~kg}^{-}$ 1 , with an average of $8,169 \mathrm{~kg} \mathrm{ha}^{-1}$ (Figure 3 ). In the environments with pre- or post-flowering stress, grain yields ranged from 2,929 to $8,674 \mathrm{~kg} \mathrm{ha}^{-1}$ and from 2,134 to 5,418 $\mathrm{kg} \mathrm{ha}^{-1}$, with averages of 4,522 and $4,240 \mathrm{~kg} \mathrm{ha}^{-1}$, respectively. Water stress post-flowering affected grain yield more than that it did pre-flowering (Figure 3). This is because the grain filling phase is the one with the highest energy expenditure from the plant and thus demands a large amount of water and nutrients. Grain yields in the environments with pre-flowering and post-flowering water stress were $45 \%$ and $48 \%$ lower, respectively, than in the environment without water stress. Grain mass was significantly reduced in the post-flowering water stress environment (Figure 4). In this environment, 50\% of the hybrids showed a thousand grain mass of between 15 and $20 \mathrm{~g}$, which was significantly lower than the mean in either of the other two environments. Pre-flowering stress did not affect the thousand grain mass. According to Magalhães et al. (2003), sorghum plants decrease their metabolism under water stress conditions, and once the water stress period ends, the normal state of development returns in a remarkable way.

Panicle harvest index and chlorophyll content of grain sorghum hybrids grown under non-water stress and water stress at pre- and post-flowering

The environment with post-flowering water stress had the greatest effect on the panicle harvest index (Figure 5): $50 \%$ of the hybrids had values between 0.70 and 0.75 , which are significantly below the averages from each of the other two environments. Panicle harvest index values closer to 1.0 are desired for the selection of new hybrids because this trait is a measure of the efficiency of photoassimilate transport to the grain; theoretically, the higher the index found in a genotype, the higher the conversion efficiency of synthesized products in that genotype and the greater the economic importance (Durães et al., 2002).

The reductions in panicle index and thousand grain mass resulted in the grain yield losses observed in the postflowering water stress environment (Figure 5). According to Silva et al. (2009), water stress during the flowering and maturation of sorghum plants causes a reduction in panicle size and consequently, in grain mass. Magalhães et al. (2003) pointed out that the effects of water stress on sorghum grain yield components can be attributed to reductions in leaf area and plant photosynthetic rate.

Chlorophyll content is another very important trait in the selection of genotypes for drought tolerance. In the environment with non-water stress, a reduction in chlorophyll content was observed only at the eighth evaluation, 79 days after sowing, which is similar to the natural senescence of the plant (Figure 6). In the preflowering water stress environment, every hybrid showed significant reductions from 37 to 51 days after sowing, the period during which the genotypes were subjected to water stress. When irrigation resumed, the plant recovered its photosynthetic capacity. In the environment with postflowering water stress, significant reductions in the SPAD index occurred from 79 days after sowing. Environments with non-water stress and post-flowering water stress displayed similar values until flowering (Figure 6), when the latter started to decrease before plant senescence.

\section{Discussion}

Grain sorghum is a succession crop, also called an off-season crop, in the Cerrado Bioma and Northeast regions of Brazil. The rainfall period there is mainly from October to April. A shortage of rainfall and prolonged drought periods are prevalent during the off-season, and sowing sorghum after February reduces yield due to water stress in June and July. Selection of tolerant cultivars may partly mitigate the reduction in grain yield caused by water stress. Effective selection requires an understanding of the effects of water stress at different stages of crop growth, as pre-flowering stress can affect different plant characteristics than postflowering stress.

Grain yield in sorghum correlates with plant height, and if water stress occurs before full plant development, yield decreases. The ideal plant height should be between $1.0 \mathrm{~m}$ and $1.5 \mathrm{~m}$ (Santos, 2005). Tall plants may lodge, and very short plants show reduced yield. Pre-flowering stress reduced plant height (Figure 1) because it occurred in the main phase of crop growth, between the 4-leaf stage and the end of booting. Disruption and delay in cell division and expansion caused by water stress reduce growth. In addition, there is a decrease in leaf and stem growth, stomatal closure, and a reduction in photosynthesis (Taiz et al., 2017). Plant resistance to water flow during desiccation occurs because plant cells shrink when dried. When roots retract, their surface may move away from soil particles that retain water, which may further damage root hairs. Moreover, suberization of the outer layer of the cortex increases resistance to water flow (Taiz et al., 2017). It was possible to obtain hybrids with heights above $1.0 \mathrm{~m}$, meaning that these hybrids have a 


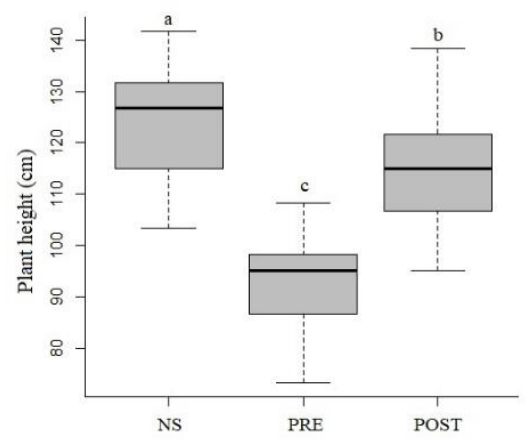

Fig 1. Boxplot of plant height $(\mathrm{cm})$ of twenty-five grain sorghum hybrids grown under non-water stress (NS), water stress at preflowering (PRE), and water stress at post-flowering (POST). Means followed by the same letter do not differ statistically from each other by Tukey test $(p<0.05)$.

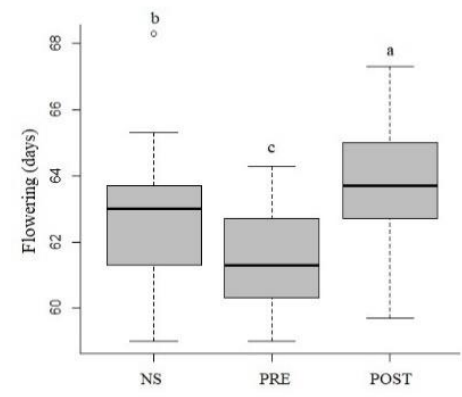

Fig 2. Boxplot of days to flowering (days) of twenty-five grain sorghum hybrids grown under non-water stress (NS), water stress at pre-flowering (PRE), and water stress at post-flowering (POST). Means followed by the same letter do not differ statistically from each other by the Tukey test $(p<0.05)$.

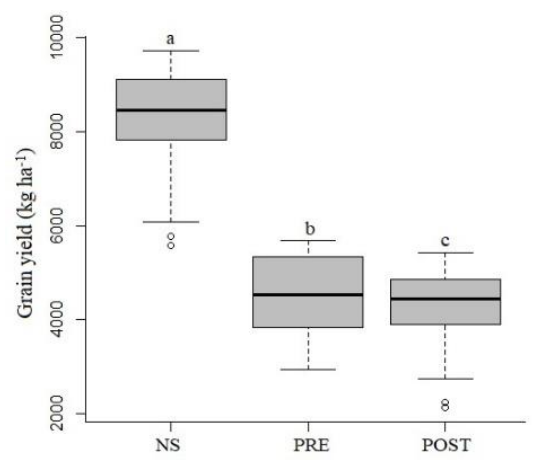

Fig 3. Boxplot of grain yield ( $\left.\mathrm{kg} \mathrm{ha}^{-1}\right)$ of twenty-five grain sorghum hybrids grown under non-water stress (NS), water stress at preflowering (PRE), and water stress at post-flowering (POST). Means followed by the same letter do not differ statistically from each other by the Tukey test $(p<0.05)$.

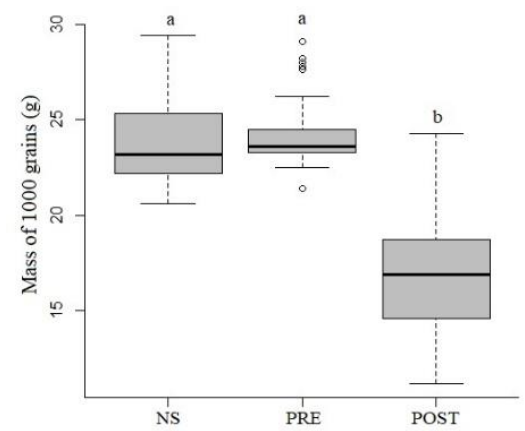

Fig 4. Boxplot of mass of 1,000 grains (g), regarding to twenty-five grain sorghum hybrids grown under non-water stress (NS), water stress at pre-flowering (PRE) and water stress at post-flowering (POST). Means followed by the same letter do not differ statistically from each other by the Tukey test $(p<0.05)$. 


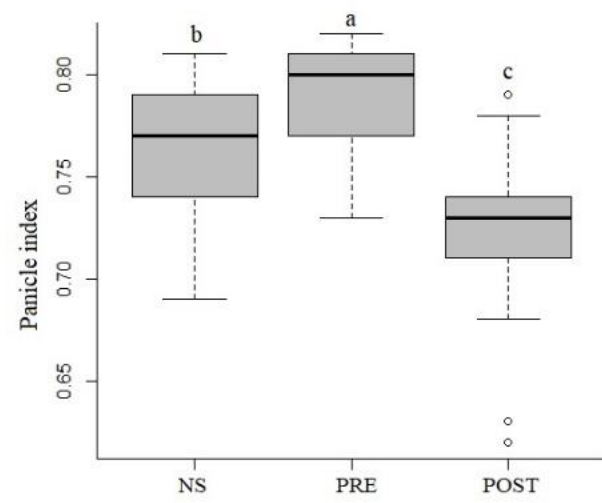

Fig 5. Boxplot of path index of twenty-five grain sorghum hybrids grown under non-water stress (NS), water stress at pre-flowering (PRE), and water stress at post-flowering (POST). Means followed by the same letter do not differ statistically from each other by the Tukey test $(\mathrm{p}<0.05)$.

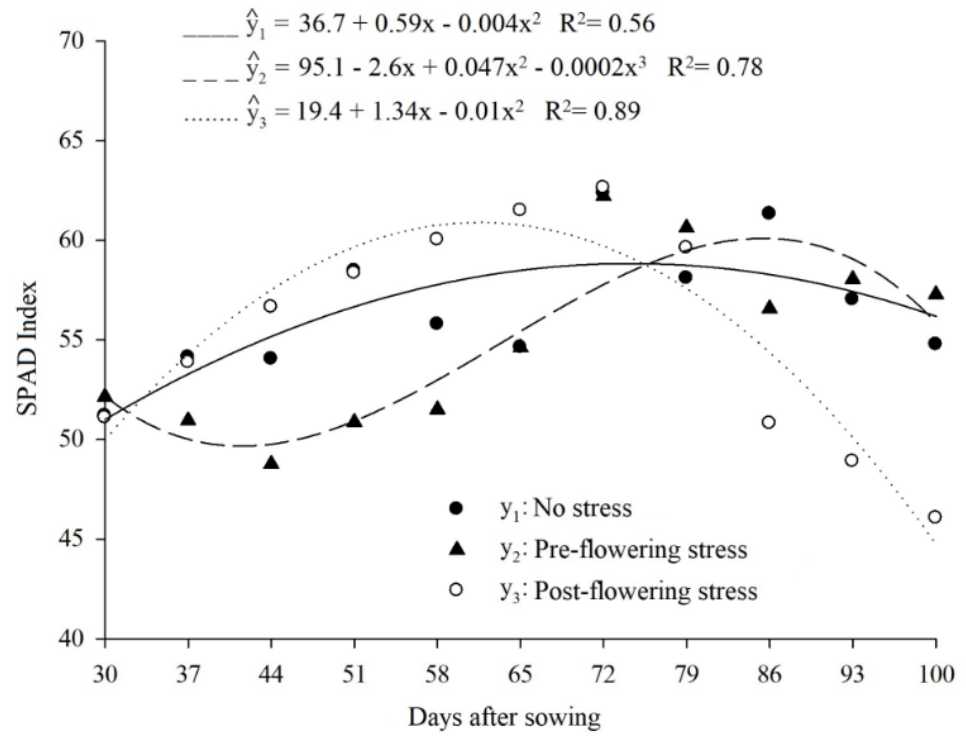

Fig 6. Mean SPAD Index values at $37,44,51,58,65,72,79,86,93$, and 100 days after sowing of twenty-five grain sorghum hybrids grown under non-water stress (NS), water stress at pre-flowering (PRE), and water stress at post-flowering (POST). Means followed by the same letter do not differ statistically from each other by the Tukey test $(p<0.05)$.

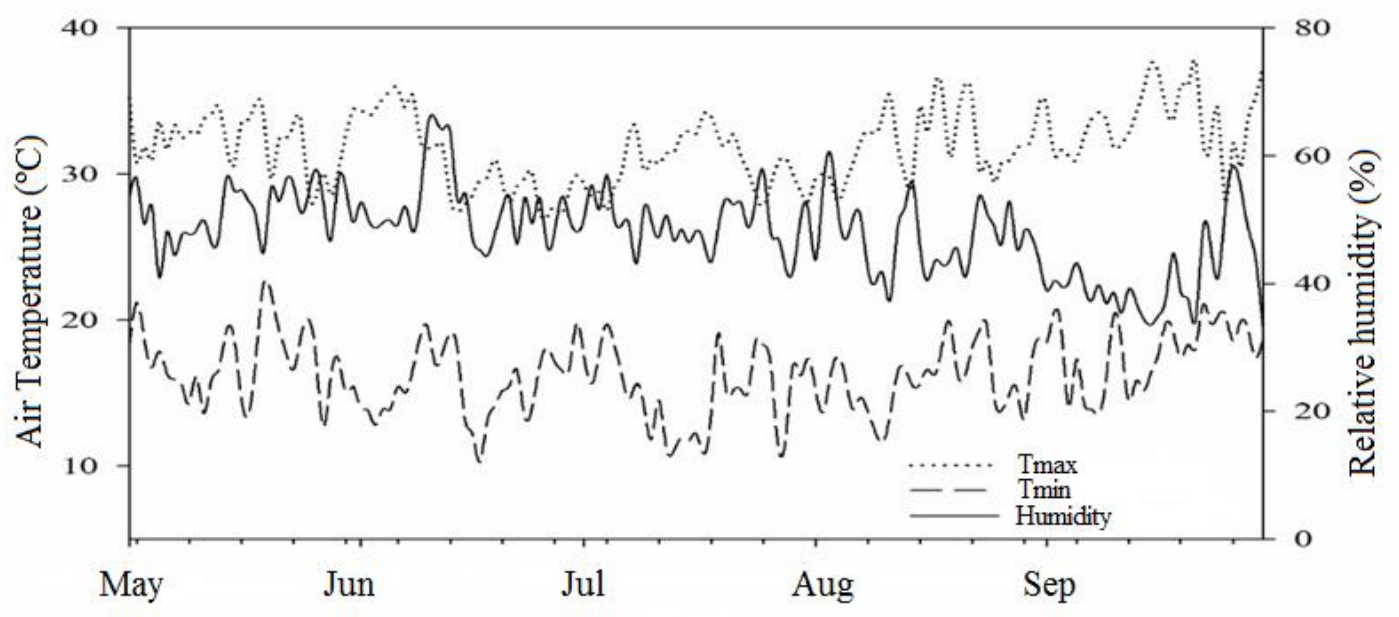

Fig 7. Daily relative humidity (\%) and maximum and minimum temperatures (으) values during the experimental period. Gorutuba Experimental Farm, Nova Porteirinha, MG, 2016. 
higher growth capacity, favoring selection based on this characteristic.

Water deficit also influenced flowering. Pre-flowering stress hastened hybrid blooming, with most occurring by 62 days after sowing. According to Tardin et al. (2013), water stress activates physiological mechanisms in sorghum that allow it to survive by accelerating its blooming. Magalhães et al. (2012) stated that water stress induces anthesis and reduces pollen longevity and germination. The earliest grain sorghum hybrids can be harvested early, decreasing the risk of crop losses due to erratic or insufficient rainfall (Silva et al., 2009). The use of hybrids with different flowering periods allows farmers to schedule crops by adapting the use of agricultural machinery (Silva et al., 2009). However, sorghum grown in the off-season should be early maturity, to minimize the duration of growth under adverse conditions. In the three environments, hybrids flowering earlier than 60 days appeared; these should also be tested later in the off-season. Sorghum is greatly affected by stress that occurs over a long period of time. When stress occurs in the vegetative phase, the plant is still able to recover, but when it occurs after flowering, the plant tends to become senescent and wilt (Batista et al., 2019). In the present study, grain yield decreased significantly in both stressed environments (Figure 3 ), indicating the importance of genotype selection studies for this trait.

The average sorghum production in Brazil is $1900 \mathrm{~kg} \mathrm{ha}^{-1}$. Based on our data, we can conclude that it is possible to select hybrids for high yield in both types of stressed environment. The ideal hybrid should produce a high yield under stress and increase its yield under non-stressed conditions. The hybrids $1168093,1239017,1244003,1324241,1516037$, and 50A70 presented above average yields in all environments.

Stress at the pre-flowering stage did not affect the thousand grain mass, but increased the panicle index, which suggests that the yield loss in this environment was due to problems in pollination or fertilization of flowers (Figure 4), reducing the panicle size and grain number (Figure 5). Borrel et al. (2014) pointed out that water deficit during pre-flowering can cause flower abortion and reduction in panicle diameter and length. The grain mass panicle index decreased in the post-flowering stress environment (Figures 4 and 5), resulting in yield loss. Water stress causes stomatal closure, reducing photoassimilated production and grain filling and consequently reducing grain weight (Magalhães et al., 2012). Chlorophyll content declined significantly as soon as irrigation was stopped (Figure 5). Under pre-flowering stress, the chlorophyll content decreased from 37 to 51 days after sowing, the period during which the genotypes were under water stress. When irrigation was resumed, the plant recovered its photosynthetic capacity. Previous studies have shown that sorghum has a great capacity to recover after drought stress (Reddy et al., 2009; Magalhães et al., 2010; Prasad et al., 2018).

Post-flowering stress caused earlier plant senescence (Figure 6). At 86 days after planting, the chlorophyll content in this environment was already below 50 , while in the other two environments the content remained above 55. A higher SPAD index suggests delayed leaf senescence, which allows photosynthesis to remain active under water stress conditions, thus favoring the production of photoassimilates and facilitating grain filling (Bekavac et al. 2007).

Water stress in plants is usually characterized by chlorophyll loss and a progressive decline in plant photosynthetic capacity. Therefore, photosynthetic pigment analysis is an important tool for evaluating the health and integrity of the internal apparatus of the cell during photosynthesis (RongHua et al. 2006) and provides a precise technique for detecting tolerant plants and quantifying their response to water stress (Jabeen et al. 2008). The reduction in chlorophyll content impaired grain filling, which was reflected in the low thousand grain weight and the low panicle index. These characteristics together resulted in a significant reduction in grain yield.

Drought is one of the most important factors affecting crop production in Brazil during the off-season. Studies have shown that climate change will increase the frequency of drought and flood occurrences, particularly in areas like the Northeast. Sorghum is well adapted to stress conditions, which are characteristic features of this region, as well as the off-season in the Cerrado. The crop requires relatively less water than other important cereals such as maize and wheat. The high genetic variability of sorghum and the relatively small size of its genome make this cereal a good model for the identification of traits that maximize grain yield in waterlimited environments. Selection for drought tolerance should consider the evaluation of characteristics in both stages of plant development, pre- and post-flowering. Plant height, days to flowering, thousand grain mass, panicle index, and chlorophyll content vary depending on the plant growth stage, but are not influenced by the environment as much as yield. Therefore, these characteristics can be used to improve sorghum breeding for increased yield.

\section{Material and Methods}

\section{Genetic material}

Twenty-five grain sorghum hybrids were evaluated: twentyone experimental hybrids (1423037, 1324241, 1324228, $1167048,1167093,1421038,1423007,1239017,1244003$, $1168093,1516037,1516043,1516049,1167017,1421007$, $1527039,1527052,1236020,1105661,1236043$, and 1421037) and four commercial hybrids (50A70, BRS373, BRS330, and BRS3318).

\section{Location}

The trials were carried out at the Gorutuba Experimental Station, belonging to Embrapa Maize and Sorghum, located in Nova Porteirinha-MG. The geographical coordinates are $15^{\circ} 48^{\prime} 10^{\prime \prime} \mathrm{S}$ and $43^{\circ} 18^{\prime} 03^{\prime \prime} \mathrm{W}$. The climate is semi-arid, with irregular rainfall. The soil of the experimental area was medium texture red-yellow latosol. This site was chosen as a model for drought tolerance tests, as its highest rainfall rates are concentrated from November to March, with a welldefined dry season from May to October, enabling water control during the set of experiments to be performed only by irrigation. The data for maximum and minimum temperatures and relative humidity during the experiments are shown in Figure 7.

\section{Experimental area}

In the environment with non-water stress, irrigation was performed from sowing to the physiological maturity of grains. In the environment with water stress at pre-flowering, irrigation was withheld from 30 to 55 days after sowing, so that water stress occurred before flowering. In the environment with water stress at post-flowering, irrigation was withheld at the plant booting stage, approximately 45 days after planting, so that water stress occurred after flowering. In the latter, irrigation was not resumed. In all 
trials, irrigation was conducted by means of a fixed conventional sprinkler system. Irrigation management was performed based on crop evapotranspiration. There was no rainfall during the experimental period, and the applied irrigation depths were $600 \mathrm{~mm}$ in the non-water stress environment, $400 \mathrm{~mm}$ in the water stress environment at preflowering, and $280 \mathrm{~mm}$ in the water stress environment at post-flowering.

\section{Experimental design}

The experimental design was a split plot, with the irrigation levels assigned to the plots and the hybrids assigned to the subplots, in a randomized complete block design. Twenty-five grain sorghum hybrids were evaluated in two environments with water stress (pre- and post-flowering) and one with nonwater stress. The plots consisted of four rows, three meters in length, with the two central rows being considered the useful area for sampling.

Soil tillage was carried out in a conventional manner, with one plowing and two harrowings pre-planting. Soon afterwards, the area was furrowed with inter-row spacing set at $0.5 \mathrm{~m}$. Fertilizer was applied according to the results of soil analysis and crop requirements, using $350 \mathrm{~kg} \mathrm{ha}^{-1}$ of formula 8-28-16 (NPK) (Santos et al., 2015), in addition to $72 \mathrm{~kg} \mathrm{ha}^{-1}$ of $\mathrm{N}$ at topdressing, using urea as a nitrogen source, 30 days after planting. Sowing was manual, with approximately 15 seeds $\mathrm{m}^{-}$ ${ }^{1}$ at a depth of $3 \mathrm{~cm}$. Plants were thinned 20 days after sowing, leaving nine plants $\mathrm{m}^{-1}$, giving a final stand of 180,000 plants ha-1.

\section{Evaluation of traits}

Plant height was determined by measuring the length between the plant collar and the panicle apex on two random plants per plot. The number of days for flowering was obtained by counting the number of days between sowing and anthesis in $50 \%$ of the flowers in the middle third of the panicle.

The chlorophyll index (SPAD) was measured weekly from 30 days after sowing, a total of 11 evaluation dates, using a SPAD-502 (Soil Plant Analysis Development, Minolta SPAD 502 Osaka, Japan) meter on four randomly selected plants from the useful area of each plot. The measurements were taken from the middle third of the last fully expanded leaf, avoiding the leaf edges, central rib region, and areas with chlorosis or necrosis.

Grain yield was estimated by weighing the grains collected from the useful area of each plot, correcting the moisture to $13 \%$, and converting the data to $\mathrm{kg} \mathrm{ha}^{-1}$. The mass of 1,000 grains was determined by weighing, in an analytical balance, three samples of one thousand grains collected from the useful area of each plot and correcting the moisture to $13 \%$. The panicle harvest index was determined as the ratio of grain mass to panicle mass collected from the useful area of each plot.

\section{Statistical Analysis}

The data were subjected to analysis of variance. When significance was indicated by the $F$ test, the means were grouped using the Tukey test $(p<0.05)$. The data are displayed using boxplot graphs, which are composed of five values: the minimum, first quartile (Q1), median (second quartile Q2), third quartile (Q3), and maximum. The height of the rectangle is defined by quartiles Q1 and Q3, and a vertical line sections the rectangle at the median value. The whiskers link Q1 and Q3 quartiles to the minimum and maximum values of the dataset, respectively. The maximum and minimum values were the largest and smallest values found in the evaluation of the characteristics. The median is the central position of the ordered data. Points below or above the maximum and minimum values are taken as discrepant values and are called outliers.

\section{Conclusions}

Water stress on sorghum in pre-flowering reduces plant height and grain yield, accelerates flowering, and increases the trail index, but does not change grain mass, while water stress on sorghum in post-flowering does not change plant height and flowering, but reduces the trail index, mass, and grain yield. In both pre-and post-flowering, water stress reduces grain production; however, if stress occurs preflowering, the plant can still recover some yield. The chlorophyll content of the sorghum plant decreased under water stress and, provided the plant did not wilt, increased again when irrigation resumed.

\section{Acknowledgments}

Research supported by Embrapa Maize and Sorghum, Coordination for the Improvement of Higher Education Personnel (CAPES), and National Council for Scientific and Technological Development (CNPq).

\section{References}

Amelework B, Shimelis H, Tongoona P, Laing M (2015) Physiological mechanisms of drought tolerance in sorghum, genetic basis and breeding methods: A review. Afr JI Agric Res. 10: 3029-3040.

Batista PSC, Carvalho AJ, Portugal AF, Bastos EA, Cardoso MJ, Torres LG, Julio MPM, Menezes, CB (2019) Selection of sorghum for drought tolerance in a semiarid environment. Genet Mol Res. 18: 1-11.

Bekavac G, Purar B, Jockovic D (2007) Corn reddening: the disease and breeding for resistance. J Plant Pathol. 89: 397404.

Belete T (2018) Breeding for Resistance to Drought: A Case in Sorghum (Sorghum bicolor (L.) Moench). J Agric Forest Meteorol Res. 1: 1-10.

Borrell AK, Muller JE, George-Jaeggli B, Oosterom EJV, Hammer GL, Klein PE, Jordan DR (2014) Drought adaptation of stay-green sorghum is associated with canopy development, leaf anatomy, root growth, and water uptake. J Exp Bot. 65: 6251-6263.

Companhia Nacional de Abastecimento (Conab). (2020). Acompanhamento da safra brasileira de grãos. Safra 2019/20, no 9. Nono Levantamento: Brasília. 7, 1-66. Retrieved on July 15, 2020 from: <https://www.conab.gov.br/info-agro/safras>

Durães FOM, Magalhães PC, Oliveira AC (2002) Índice de colheita genético e as possibilidades da genética fisiológica para melhoramento do rendimento do milho. Rev Bras Milho Sorgo. 1: 33-40.

Jabeen F, Shahbaz M, Ashraf M (2008) Discriminating some prospective cultivars of maize (Zea mays L.) for drought tolerance using gas exchange characteristics and proline contents as physiological marker. Pak J Bot. 40: 2329-2343.

Magalhães PC, Albuquerque PEP, Viana JHM (2012) Resposta fisiológica do sorgo ao estresse hídrico em casa de vegetação. Sete Lagoas: Embrapa Milho e Sorgo. 21 p. (Embrapa Milho e Sorgo. Boletim de Pesquisa e Desenvolvimento, 46). 
Magalhães PC, Durães FOM, Schaffert RE (2003) Fisiologia da planta de sorgo. Sete Lagoas: Embrapa Milho e Sorgo. 46p. (Embrapa Milho e Sorgo - Circular Técnica, 86).

Magalhães PC, Pereira FJ, Schaffert RE, Magalhaes JV (2010) Características morfofisiológicas e de produção de seis genótipos de sorgo submetidos ao estresse hídrico. Sete Lagoas: EMBRAPA-CNPMS. 16p, (Boletim de Pesquisa e Desenvolvimento).

Menezes CB, Saldanha DC, Santos CV, Andrade LC, Julio MPM, Portugal AF, Tardin FD (2015) Evaluation of grain yield in sorghum hybrids under water stress. Genet Mol Res. 14: 12675-12683.

Mutava RN, Prasad PVV, Tuinstra MR, Kofoid KD, YU J (2011). Characterization of sorghum genotypes for traits related to drought tolerance. Field Crops Res. 123: 10-18.

Prasad PVV, Djanaguiraman M, Jagadish SVK, Ciampitti IA (2018) Drought and high temperature stress and traits associated with tolerance. In: Ciampitti I, Prasad PVV (eds) Sorghum: State of Art and Future Perspectives. Agronomy Monographs v.58.

Reddy BVS, Ramesh S, Reddy PS, Kumar AA (2009) Genetic Enhancement for Drought Tolerance in Sorghum. Plant Breed Rev. 31: 189-222.

Reddy PS (2019) Breeding for Abiotic Stress Resistance in Sorghum. In: ARUNA C, Visarada KBRS, Bhat BV, Tonapi VA Breeding sorghum for diverse end uses. Duxford. p.325340.

Rong-Hua L, Pei-Pol G, Baumz M, Grand S, Ceccarelli S (2006) Evaluation of Chlorophyll Content and Fluorescence Parameters as Indicators of Drought Tolerance in Barley. Agric Sci China. 5: 751-757.

Rosenow DT, Ejeta G, Clark LE (1996) Breeding for pre-and post-flowering drought stress resistance in sorghum. In: International conference on genetic improvement of sorghum and pearl millet, 1996, Lubbock, Texas.
Santos FC, Resende AV, Coelho AM (2015) Exigências nutricionais e adubação. In: Pereira Filho IA, Rodrigues JAS (Ed.) Sorgo: o produtor pergunta, a Embrapa responde. Brasília, DF: Embrapa, cap. 6, 81-97. (Coleção 500 perguntas, 500 respostas).

Santos FG, Casela CR, Waquil JM (2005) Melhoramento de sorgo In: Borém A (Ed.) Melhoramento de espécies cultivadas. 2a ed. Viçosa, MG: UFV, 605-658.

Shao H, Chu L, Jaleel CA, Zhao C (2008) Water-deficit stress induced anatomical changes in higher plants. C R Biol. 331: 215-225.

Silva AG, Barros AS, Silva LHCP, Moraes EB, Pires R, Teixeira IR (2009) Avaliação de cultivares de sorgo granífero na safrinha no sudoeste do estado de Goiás. Pesq Agropec Trop. 39: 168-174.

Taiz L, Zeiger E, Moller IM, Murphy A (2017) Fisiologia e Desenvolvimento Vegetal. Artmed Editora LTDA. Porto Alegre. 888p.

Tardin FD, Almeida Filho JE, Oliveira CM, Leite CEP, Menezes CB, Magalhaes PC, Rodrigues JAS, Schaffert RE (2013) Avaliação agronômica de híbridos de sorgo granífero cultivados sob irrigação e estresse hídrico. Rev Bras Milho Sorgo. 12: 102-117.

Tuinstra MR, Grote EM, Goldsbrough PB, Ejeta G (1997) Genetic analysis of post-flowering drought tolerance and components of grain development of Sorghum bicolor (L.) Moench. Mol Breed. 3: 439-448.

Wagaw K (2019) Review on mechanisms of drought tolerance in sorghum (Sorghum bicolor (L.) Moench) basis and breeding methods. Acad Res J Agri Sci Res. 7: 87-99.

Xu WM, Subudhi PK, Crasta OR, Rosenow DT, Mullet JE, Nguyen HT (2000) Molecular mapping of QTLs conferring stay-green in grain sorghum (Sorghum bicolor L. Moench). Genome, 43: 461-469, 2000. 